\title{
Time-Varying Exchange Rate Basket in China from 2005 to 2009
}

\author{
Jarko Fidrmuc
}

\author{
CESIFO WORKING PAPER NO. 3147 \\ CAtegory 7: Monetary Policy And International Finance
}

August 2010

Presented at CESifo Area Conference on Global Economy, February 2010

\footnotetext{
An electronic version of the paper may be downloaded

- from the SSRN website:

- from the RePEc website: wWw.SSRN.com

Www.RePEc.org

- from the CESifo website:

www.CESifo-group.org/wp
} 


\title{
Time-Varying Exchange Rate Basket in China from 2005 to 2009
}

\begin{abstract}
We use the Kalman filter to estimate the structure of the secret currency basket of the renminbi based on daily data between 2005 and 2009. The currency weights of selected currencies are modeled as stochastic processes (random walks). The official announcement of the new exchange rate regime in July 2005 with the introduction of a secret currency basket was followed by a smooth appreciation against the US dollar. Other currencies did not play a major role. We show that the US dollar again received a higher weight in the Chinese exchange rate policy already before the financial crisis of 2008 .
\end{abstract}

JEL-Code: G33, G21, C25.

Keywords: exchange rate regime, Kalman filter, financial crisis.

\author{
Jarko Fidrmuc \\ Oesterreichische Nationalbank (OeNB) \\ Foreign Research Division \\ Postfach 61 \\ Austria - 1011 Vienna \\ jarko.fidrmuc@oenb.at
}

July 2010

This research was largely completed during author's stay at the University of Munich, whose hospitality is appreciated and acknowledged. The author would like to thank Iikka Korhonen, Sylvia Kaufmann, Doris Ritzberger-Grünwald, Philipp Mayer, Jin Cao, Hubert Gabrisch, Ken Iwatsubo, Yin-Wong Cheung, Elisabeth Beckmann, Xiaobo Zhang, Aaron Mehrotra, Jeffrey Frankel, John Whalley and other participants of the CESifo Area Conference on Global Economy in Munich in February 2010 for helpful comments and suggestions. I acknowledge language advice by Irene Popenberger. The opinions are those of the author and do not necessarily reflect the viewpoint of the Oesterreichische Nationalbank or the Eurosystem. I acknowledge the CESIUK support from the Operational Program of Research and Development in the framework of the European Regional Development Fund (ERDF). 


\section{Introduction}

China today boasts an extensive modern industrial economy with booming urban regions. The country's high trade growth is supported by expanding exports (Bussière et. al., 2008) and large foreign direct investment (FDI) flows (Eichengreen and Tong, 2005). Not surprisingly, growth in the world's most populous country has changed the distribution of economic activities across the world. According to the OECD (2010), the share of Chinese GDP in the world economy valued at market exchange rates increased from $1.7 \%$ to $7.2 \%$ between 1980 and 2008 . In terms of purchasing-power-adjusted prices, the share of Chinese output in the world economy was $11.3 \%$ as of 2008 .

Corresponding to the rising importance of the Chinese economy, the country's economic developments and policies, too, are of great and increasing consequence for its trading partners. Exchange rate regimes and exchange rate levels belong to the most controversial issues in the world economy. Korhonen and Ritola (2009), for example, found 29 academic papers dealing with the misalignment (overvaluation) of the exchange rate of the renminbi.

The analysis of the exchange rate regime in China takes an important place in this discussion. Demands that China should adopt a more flexible exchange rate regime occur frequently. On July 21, 2005, the People's Bank of China (PBC) moderately revaluated the exchange rate against the US dollar by initially about $2 \%$. At the same time, the exchange rate regime was changed from a de facto peg to the US dollar to a more flexible peg to a basket of currencies with narrow fluctuation bands. On the one hand, this was generally seen as a promising change of Chinese monetary policy, with important implications for the whole region and the world economy. On the other hand, the international markets observed the development rather skeptically as they believed that the old policy would be continued under the new regime. These expectations were supported by the secret structure of the currency basket and a continuing stability of the exchange rate against the US dollar, which was empirically confirmed in several papers (Frankel, 2006, and Funke and Gronwald, 2008). Moreover, deviations between de facto and de jure exchange rate regimes are in general widespread across countries (see Reinhart and Rogoff, 2002 and 2004). In particular, pursuing a more rigid exchange rate policy than announced corresponds to the so called fear-of-floating phenomenon (Calvo and Reinhart, 2002). In this vein, McKinnon (2006), and McKinnon et al. (2009) 
discuss various arguments including carry trades for maintaining some degree of exchange rate stability in China.

In fact, the renminbi's exchange rate has again stabilized at about 6.8 RMB per USD (see Figure 1) in July 2008 without any official explanation of this policy change. ${ }^{1}$ Thus the exchange rate appreciated by about $20 \%$ between July 2005 and July 2008. In the subsequent period, the exchange rate remained largely stable. There were only moderate fluctuations in a narrow band of about $\pm 0.5 \%$, which occurred mainly in the second half of 2008. This again sparked international demands for exchange rate liberalization in China. Following these demands, China announced a return to the managed float on June 19, 2010. While it is impossible to analyze the new exchange rate policy in this paper, the presented results can shed some light on the first period of the managed float in China between July 2005 and the end of 2008.

The policy change of July 2008 gave rise to several questions which were not addressed in the previous analyses. Was it the intention of the Chinese monetary authorities to appreciate the exchange rate by $20 \%$ within three years? Did other currencies play a role at all in the determination of the Chinese exchange rate? Or was the exchange rate stabilization in July 2008 an abrupt policy change caused by the worsening state of the world economy, as argued by the People's Bank of China (PBC, 2010)? Finally, we pose the question whether the Chinese exchange rate policy was influenced by the outbreak of the financial crisis in September 2008.

Our results indicate that the reintroduction of a fixed exchange rate policy was not an abrupt change of Chinese monetary policy. Moreover, the new policy was introduced already before the financial crisis erupted in September 2008. Notably, the return to a de facto fixed exchange rate allows us to determine whether we can timely detect such policy changes with high-frequency exchange rate data. We document that the standard approach to analyzing a secret currency basket (i.e. by rolling regressions with differenced data) has failed to detect the policy change of July 2008. Therefore, we propose an alternative estimation of time-varying parameters with the Kalman filter,

\footnotetext{
${ }^{1}$ Only later, for example in June 2010, the People's Bank of China stressed the importance of exchange rate stability for the development of the Chinese economy in the aftermath of the financial crisis.
} 
which uses non-differenced data. This approach shows a change in parameters immediately after the exchange rate policy was changed.

The remainder of the paper is structured as follows. The next section describes methods for the estimation of time-varying exchange rate baskets. Section 3 describes the data. Sections 4 and 5 report the results of our analysis using (rolling) ordinary least squares (OLS) regressions and time-varying coefficients, respectively. Section 6 concludes the paper.

Figure 1: Exchange Rate of the Renminbi against the US Dollar, January 1996 to November 2009

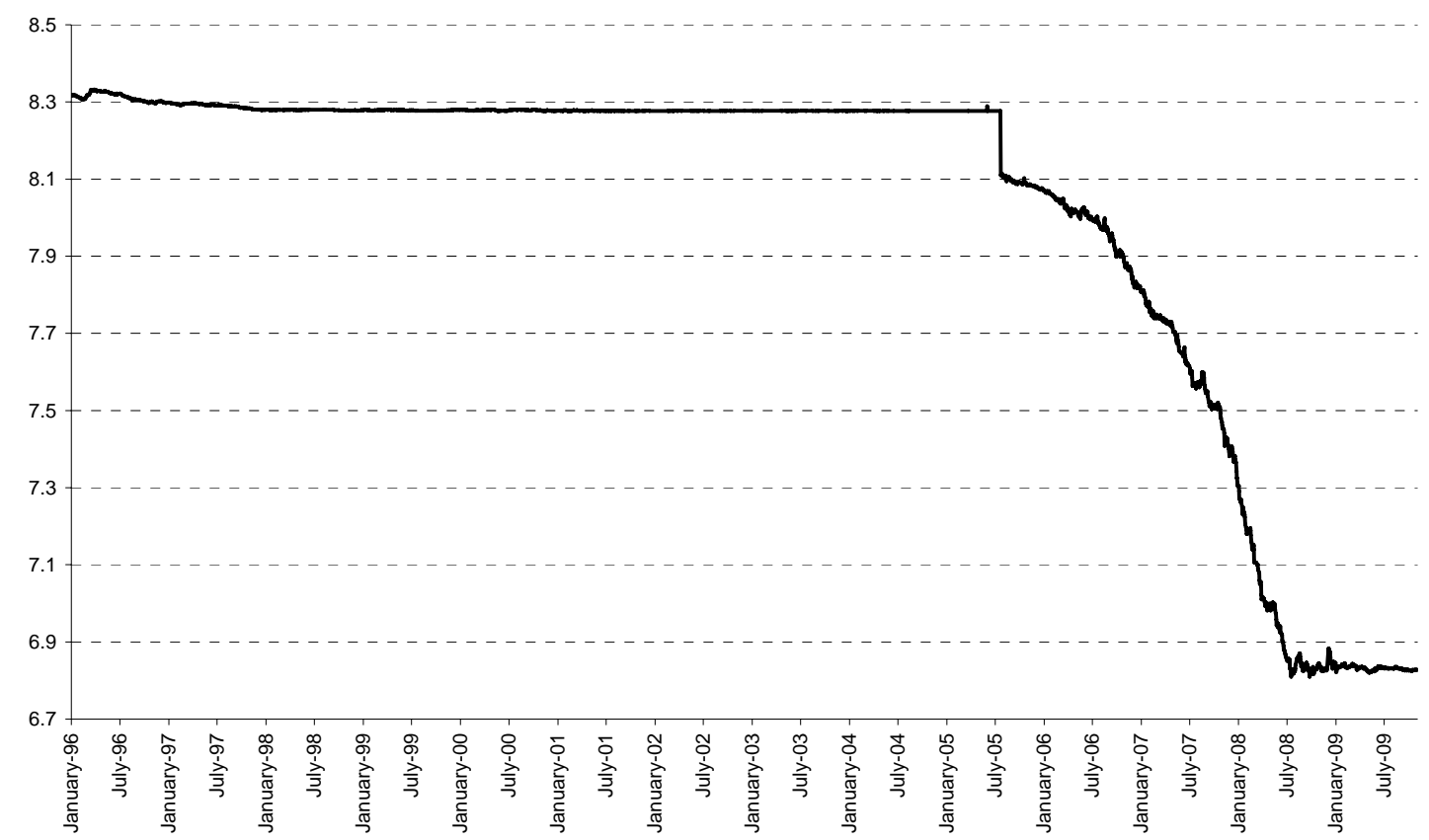

Source: Datastream.

\section{Estimation of the Implicit Currency Basket}

According to a statement released by the People's Bank of China on August 10, 2005, the secret basket for the Chinese exchange rate policy included, above all, the US dollar (USD), the Japanese yen (JPY), the euro (EUR), and the South Korean won (KRW). Several other currencies, namely the Australian dollar (AUD), the Canadian dollar (CAD), the pound sterling (GBP), the Malaysian ringgit (MYR), the Russian ruble 
(RUB), the Singapore dollar (SGD), and the Thai baht (THB), should also play some role. Moreover, the actual value of the exchange rate could fluctuate within narrow bounds. According to Funke and Gronwald (2008), the fluctuation margins were initially about $\pm 0.15 \%$ for the US dollar and extended to about $\pm 0.5 \%$ on May 18 , 2007. The fluctuation bands for other currencies might be slightly larger, up to $\pm 1.0 \%$ according to Funke and Gronwald (2008).

Although the structure of the currency basket is secret, the implicit weights can be estimated on the basis of actual exchange rate developments of the renminbi against the list of potential target currencies. Originally this approach was proposed by Frankel and Wei $(2007,2008)$ and then followed in the literature. In so far as the exchange rates are generally believed to follow a random walk (see Meese and Rogoff, 1983), a simple estimation of the relationship between the currencies would likely be subject to the spurious regression problem. This is especially important for rolling or subsample (e.g. for each month) regressions with a relatively low number of observations. Therefore, the estimation of the renminbi's exchange rate basket is stated in first differences,

$$
\Delta e_{r m b / c u r, t}=\beta_{1}+\beta_{2} \Delta e_{u s d / c u r, t}+\beta_{2} \Delta e_{e u r / c u r, t}+\beta_{2} \Delta e_{j p y / c u r, t}+\cdots+\varepsilon_{t},
$$

where $\Delta e$ is the first difference of the exchange rate log of the renminbi and selected currencies against a base currency, which is denoted by cur. In general, previous analyses concluded that only the US dollar, and to a much lesser extent the euro, could have significant informative value for the development of the renminbi's exchange rate.

Although equation (1) should be appropriate for estimating the currency baskets, it is also subject to possible drawbacks, which have been ignored in the previous literature. First, the relationship has to be estimated over some time period, while the weights may be subject to frequent or even continuous changes. ${ }^{2}$ Therefore, the majority of studies estimate rolling regressions and usually use a comparatively short window. However, this often results in a relatively low number of observations despite the use of daily data. Moreover, the structural changes are then artificially smoothed and they cannot be clearly attributed to a specific date. This approach can also result in higher and correlated errors from the regression. Funke and Gronwald (2008) show that the

\footnotetext{
${ }^{2}$ Frankel and Xie (2010) discuss the estimation of structural changes of exchange rate policies for several countries, but excluding China.
} 
$\mathrm{ARCH}$ test rejects the null of homoscedasticity of the error term in the OLS regression of (1).

Second, estimation (1) is based on differenced data, while the actual exchange rate policy is likely to consider the level of the exchange rate. This is especially important as the exchange rate of the renminbi is announced to move within a narrow fluctuation band. For the less important currencies, fluctuation bands of $\pm 1.0 \%$ may be sufficient to make the estimates fuzzy.

We address both points of criticism. First, we account for the possibility that coefficients are changing gradually by using an alternative estimation method. Following Harvey (1989) and Ogawa and Sakane (2006), the estimated structure of the currency basket with time-varying weights is estimated using the Kalman filter in the following form:

$$
\Delta e_{r m b / c u r, t}=\alpha+\omega_{u s d / c u r, t} \Delta e_{u s d / c u r, t}+\omega_{u s d / c u r, t} \Delta e_{e u r / c u r, t}+\omega_{u s d / c u r, t} \Delta e_{j p y / c u r, t}+\cdots+\varepsilon_{t},(2 a)
$$

where $\alpha$ is the intercept and the remaining parameters are estimated as time-varying parameter processes which follow a random walk

$$
\omega_{i, t}=\omega_{i, t-1}+\eta_{i, t} \text { where } i=\text { usd/cur, eur/cur, jpy/cur, ... }
$$

Second, we use data in levels to see whether non-differenced time series are more informative on changes in implicit exchange rate policy. In this specification, we do not take logs of exchange rates, which are therefore denoted by $E$. The estimation equation can be stated as

$$
E_{r m b / c u r, t}=\alpha+\omega_{u s d / c u r, t} E_{u s d / c u r, t}+\omega_{u s d / c u r, t} E_{\text {eur/cur }, t}+\omega_{u s d / c u r, t} E_{j p y / c u r, t}+\cdots+\varepsilon_{t},
$$

where time-varying coefficients $\omega$ are defined as in equation (3). In addition to selected currencies, we also included an appreciation trend to specification (2b). This variable shows whether there is an autonomous appreciation trend in the Chinese exchange rate policy. The trend is defined so that a positive value of the estimated parameter corresponds to an appreciation of the renminbi.

\section{Data Description}

We have daily exchange rate data for the period from January 1996 to November 2009 for the most important currencies from the list published by the People's Bank of China, 
namely USD, JPY, EUR, KRW, and THB. In the empirical part we concentrate on the period with relatively variable (appreciating) exchange rates between March 2005 and January 2009. The earlier literature and our preliminary analysis on the remaining currencies showed that they are not informative for the development of the renminbi's exchange rate. All data were obtained from Datastream.

We selected the Australian dollar as a reference currency following the argument of Calvo and Reinhart (2002) that it can be considered to be a typical free floating currency of a relatively small country. We are aware that the Australian dollar is included in the list of the target currencies published by the People's Bank of China. Given that the previous analyses did not find any significant de facto weight for this currency, we believe that the possible bias is negligible. We do not include the Swiss franc (CHF), following Funke and Gronwald (2008), because the franc may be oriented towards the euro, especially in the more recent period. Reynard (2008) shows, for example, that the fluctuations of the Swiss franc against the euro have declined since the introduction of the euro in 1999. This could bias the results for the euro, which are particularly interesting.

\section{Estimation in First Differences}

We start with the estimation of Frankel's and Wei's (2007 and 2008) regression of (1) in first differences using OLS (see Table 1). We compare the results for the whole period available (August 8, 2005 to January 29, 2009) with two subperiods at the beginning and the end of the sample. Thus, we can also see how the currency weights have evolved since August 2005. In particular, we take 100 observations at the beginning and the end of our sample. At first glance, the OLS performs very well for all periods, as can be seen from high test $t$-statistics and $\mathrm{R}^{2}$ values. However, the residual statistics reveal more problems especially for the first subperiod. The residuals show significant autocorrelation in all specifications (see e.g. the Durbin-Watson statistics) and significant heteroscedasticity above all at the beginning of the sample. In general, a similar picture can be observed for several subperiods, especially those characterized by some volatile movements on international foreign exchange markets. The relatively good residual statistics at the end of the sample are rather an exception than a rule. 
Table 1: Currency Weights Estimated by OLS (First Differences)

\begin{tabular}{|c|c|c|c|c|c|c|}
\hline & Aug. 05 - Jan. 09 & & Aug 05 - Dec. 05 & & Sep. 08 - Jan 09 & \\
\hline \multirow[t]{2}{*}{ USD } & 0.784 & & 0.929 & & 0.736 & \\
\hline & $(78.292)$ & & (43.044) & & (27.704) & \\
\hline \multirow[t]{2}{*}{ EUR } & 0.027 & $* * *$ & -0.005 & & 0.021 & $* *$ \\
\hline & (3.677) & & $(-0.596)$ & & (2.018) & \\
\hline \multirow[t]{2}{*}{ JPY } & 0.020 & $* * *$ & 0.001 & & 0.004 & \\
\hline & (4.632) & & $(0.105)$ & & $(0.469)$ & \\
\hline \multirow[t]{2}{*}{ KRW } & 0.001 & & 0.013 & & 0.000 & \\
\hline & $(0.389)$ & & $(0.962)$ & & $(-0.034)$ & \\
\hline \multirow[t]{2}{*}{ THB } & 0.031 & $* * *$ & 0.023 & & 0.086 & ** \\
\hline & (3.147) & & $(1.071)$ & & $(2.615)$ & \\
\hline \multirow[t]{2}{*}{ Constant } & -0.020 & $* * *$ & -0.006 & & -0.001 & \\
\hline & $(-5.052)$ & & $(-1.422)$ & & $(-0.116)$ & \\
\hline No. of obs. & 906 & & 100 & & 100 & \\
\hline Adjusted $\mathrm{R}^{2}$ & 0.989 & & 0.995 & & 0.998 & \\
\hline AIC & -1.387 & & -3.442 & & -1.796 & \\
\hline SIC & -1.355 & & -3.286 & & -1.640 & \\
\hline DW & 2.076 & & 2.671 & & 2.173 & \\
\hline \multirow[t]{2}{*}{ LQ(4), RES } & 6.282 & & 13.401 & $* * *$ & 4.950 & \\
\hline & [0.179] & & [0.009] & & {$[0.293]$} & \\
\hline \multirow[t]{2}{*}{ LQ[10], RES } & 17.694 & * & 18.204 & * & 19.665 & ** \\
\hline & {$[0.060]$} & & {$[0.052]$} & & {$[0.033]$} & \\
\hline \multirow[t]{2}{*}{ LQ[4], RES } & 10.269 & $* *$ & 21.924 & $* * *$ & 0.1377 & \\
\hline & {$[0.036]$} & & {$[0.000]$} & & [0.998] & \\
\hline \multirow[t]{2}{*}{ LQ[10], RES } & 12.376 & & 23.202 & ** & 3.8934 & \\
\hline & {$[0.261]$} & & {$[0.010]$} & & {$[0.952]$} & \\
\hline \multirow[t]{2}{*}{$\mathrm{ARCH}[4]$} & 2.320 & * & 10.538 & *** & 0.037 & \\
\hline & {$[0.055]$} & & {$[0.000]$} & & [0.997] & \\
\hline \multirow[t]{2}{*}{ ARCH[10] } & 1.106 & & 4.848 & $* * *$ & 0.324 & \\
\hline & {$[0.355]$} & & {$[0.000]$} & & {$[0.973]$} & \\
\hline
\end{tabular}

Note: $t$-statistics computed are in parentheses and $p$-values are reported in brackets. ${ }^{*}, * *, * *$ denote significance at the 10,5 and $1 \%$ level, respectively. 
Table 2: Time-Varying Weights (Final States Estimates) Estimated by Kalman Filter in First Differences

\begin{tabular}{|c|c|c|c|c|}
\hline & USD & USD\&EUR & USD\&JPY & USD\&EUR\&JPY \\
\hline & Jan 3, 2005- & Jan: 3, 2005- & Jan 3, 2002- & Jan. 3, 2005- \\
\hline & Jan 29, 2009 & Jan. 29, 2009 & Jan: 29, 2009 & Jan. 29, 2009 \\
\hline \multirow[t]{2}{*}{ USD, first differences } & $0.991^{* * *}$ & $1.003^{* * *}$ & $0.977^{* * *}$ & $0.979^{* * *}$ \\
\hline & (686.235) & (155.894) & (71.195) & $(23.571)$ \\
\hline \multirow[t]{2}{*}{ EUR, first differences } & & 0.009 & & 0.007 \\
\hline & & $(1.502)$ & & $(0.298)$ \\
\hline \multirow[t]{2}{*}{ JPY, first differences } & & & $0.022^{*}$ & 0.014 \\
\hline & & & $(1.744)$ & $(0.439)$ \\
\hline Log-Likelihood & 5438.537 & 5382.645 & 4748.961 & 4386.135 \\
\hline AIC & -10.21905 & -10.112 & -8.923 & -8.239 \\
\hline SIC & -10.20971 & -10.098 & -8.914 & -8.225 \\
\hline No of obs. & 1064 & 1064 & 1064 & 1064 \\
\hline
\end{tabular}

Notes: $z$-statistics are in parentheses. 
Figure 2: Time-Varying Structure of the Currency Basket in China Estimated by Kalman Filter in First Differences

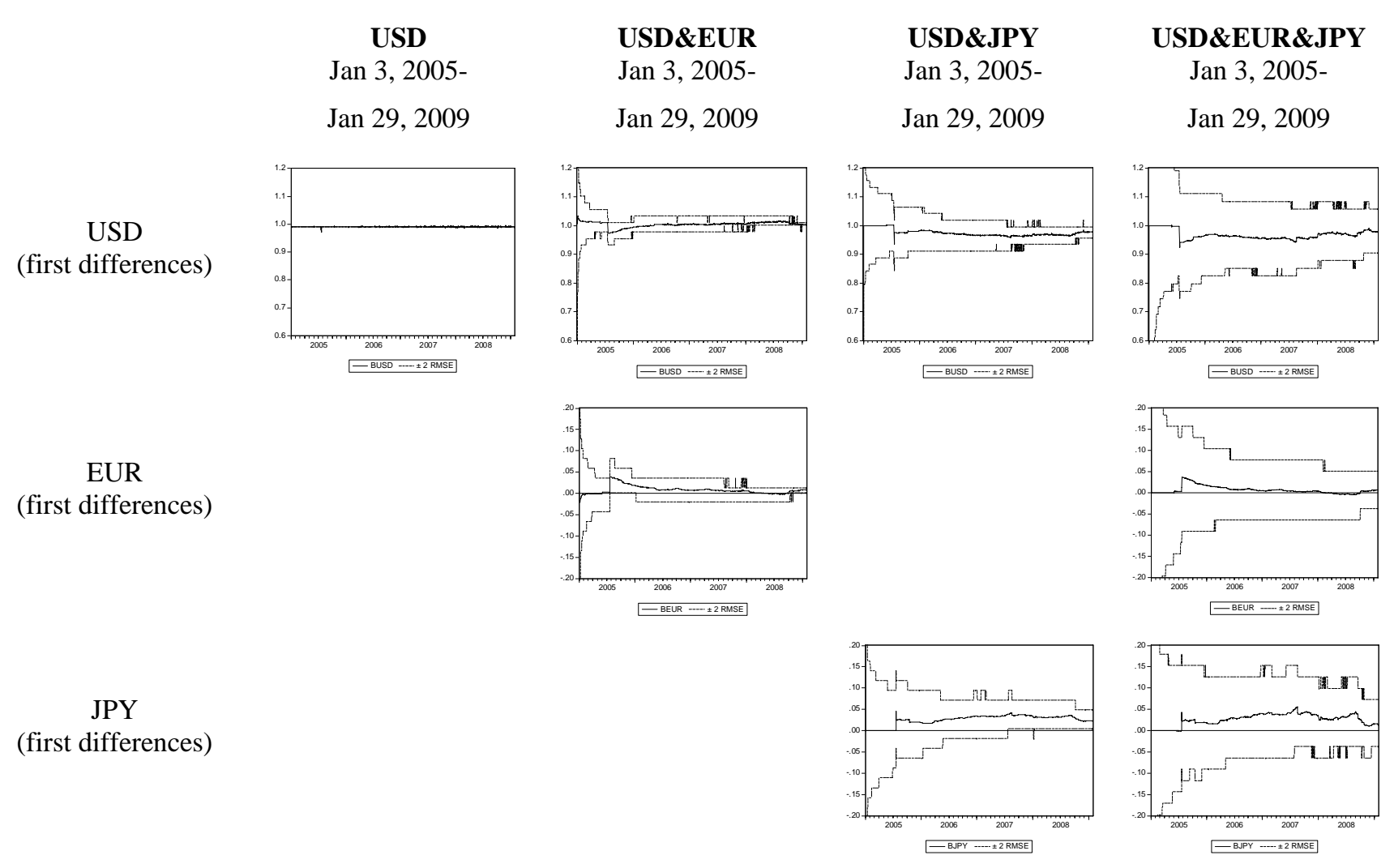


The estimation shows that the coefficient of the US dollar has declined from 1 to about 0.74 . Thus, its role remains still comparably high. The last available subperiods show also a positive coefficient for the euro and the Thai baht, but both coefficients are very small. There is mixed evidence on the appreciation trend, which is significant for the whole period, but insignificant for the subperiods. According to the OLS results, both the Japanese yen and the Korean won are insignificant.

However, the results for the end of the sample (September 2008 to January 2009) are rather surprising. While a visual inspection of Figure 1 reveals clearly that there was a return to the de facto exchange rate peg, this is not confirmed in the corresponding regression. Actually, the US dollar coefficient is surprisingly low, while the coefficients for the euro and the Thai baht are significant. Frankel (2009) presents the same finding for the euro in the second half of 2008. Thus, the standard methodology based on differenced data fails to reveal the policy change, because it puts too much weight on relatively negligible fluctuations of the exchange rate around the new implicit target.

The autocorrelation of residuals revealed in Table 1 may be caused by structural changes during the estimation period. Therefore, we estimate time-varying weights for different currencies as specified in equation (2a) using the Kalman filter. However, this approach also confirms the previous results (see Table 2 and Figure 2). ${ }^{3}$ The estimation of the US dollar peg without reflecting other currencies (see first column in Figure 2) reveals nearly no change in the estimated weights for the dollar. Actually, we can see that the coefficient was close to unity over the whole period analyzed, with the exception of the exchange rate appreciation on July 21. The results are similar if we include also the euro or the Japanese yen. In these specifications, we can see a slight decline of the US dollar's weight and a corresponding increase in the weight of other currencies, especially the Japanese yen. These results are similar to the earlier finding by Ogawa and Sakane (2006). However, the estimated currency basket returns to a US dollar peg as early as 2006. Finally, the estimated results do not indicate any change of exchange rate policy in the second half of 2008. We consider this failure to reveal the

\footnotetext{
${ }^{3}$ Figure 2 presents the results in a table where each column shows one specification with one or several currencies which are possibly included in the currency basket of the renminbi. The presentation thus largely corresponds to a standard table with regression results. However, each time-varying coefficient is shown as a figure including standard confidence bands.
} 
policy change in the second half of 2008 a major drawback of using differenced data in the estimation of an implicit exchange rate basket.

\section{Time-Varying Approach in Levels}

So far, the estimation of the implicit currency basket has provided rather mixed results. On the one hand, we can see that the exchange rate policy was oriented mainly towards the US dollar, also during the relatively flexible period between July 2005 and summer 2008. On the other hand, we get confusing results for the estimation in the last period (September 2008 to January 2009), when the policy returned to a de facto exchange rate peg.

We address this issue by estimating implicit currency weights using the Kalman filter in levels. The Kalman filter is appropriate for the estimation of the relationship between integrated variables. Therefore, we estimate specification (2b) with timevarying coefficients using the Kalman filter (see Table 3 and Figure 3). We start with a simple specification for the US dollar as the single explanatory currency of the renminbi's exchange rate. The results are highly robust. The development pattern of estimated coefficients corresponds closely to the announced policy changes. So the first break in the coefficient of the US dollar is on July 21, 2005, which corresponds to the revaluation of the currency. According to our estimation, the parameter changed from 0.997 to 0.922 . Furthermore, the parameter stabilized at a new level of 0.82 (reflecting the appreciation by approximately $20 \%$ ) already in mid-July 2008 .

Next, we include the euro or the Japanese yen ${ }^{4}$ to (1). The estimated parameter for the US dollar remains robust, but the confidence bands expand if another currency and a trend are included. The results reveal that the euro and the Japanese yen have positive but low weights when included separately in the estimation. It seems that the yen was more important than the euro. Nevertheless, the final state estimates (Table 3) show that the overall impact of these variables on the renminbi's exchange rate remained low between 2005 and 2008.

\footnotetext{
${ }^{4}$ The results for other currencies are available upon request from the author.
} 
Table 3: Time-Varying Weights (Final States Estimates) Estimated by Kalman Filter in Levels

\begin{tabular}{|c|c|c|c|c|c|}
\hline & USD & USD\&EUR & USD\&JPY & USD\&EUR\&JPY & USD\&TREND \\
\hline & Jan $3,2005-$ & Jan: 3, 2005- & Jan 3, 2002- & Jan. 3, 2005- & Jan. 3, 2005- \\
\hline & Jan 29, 2009 & Jan. 29, 2009 & Jan: 29, 2009 & Jan. 29, 2009 & Jan. 29, 2009 \\
\hline \multirow[t]{2}{*}{ USD } & $0.811^{* * *}$ & $0.806^{* * *}$ & $0.787^{* * *}$ & $0.778^{* * *}$ & 0.825 \\
\hline & $(846.152)$ & $(120.575)$ & (204.208) & $(108.486)$ & $(182.506)$ \\
\hline \multirow[t]{2}{*}{ EUR } & & 0.010 & & 0.009 & \\
\hline & & $(1.006)$ & & $(1.055)$ & \\
\hline \multirow[t]{2}{*}{ JPY } & & & $0.029^{* * *}$ & $0.029^{* * *}$ & \\
\hline & & & $(6.411)$ & $(6.911)$ & \\
\hline \multirow[t]{2}{*}{ Appreciation Trend } & & & & & 0.070 \\
\hline & & & & & $(48.079)$ \\
\hline \multirow[t]{2}{*}{ Constant } & 1.770 & 1.573 & 1.790 & 2.093 & 24.057 \\
\hline & $(5.265)$ & (4.009) & $(2.231)$ & $(0.694)$ & $(3.773)$ \\
\hline Log likelihood & 639.823 & 633.505 & 651.0939 & 645.222 & 606.704 \\
\hline AIC & -1.199 & -1.185 & -1.218 & -1.205 & -1.135 \\
\hline SIC & -1.190 & -1.171 & -1.204 & -1.187 & -1.121 \\
\hline No of obs. & 1064 & 1064 & 1064 & 1064 & 1064 \\
\hline
\end{tabular}

Notes: $z$-statistics are in parentheses. 
Figure 3: Time-Varying Structure of the Currency Basket in China Estimated by Kalman Filter in Levels

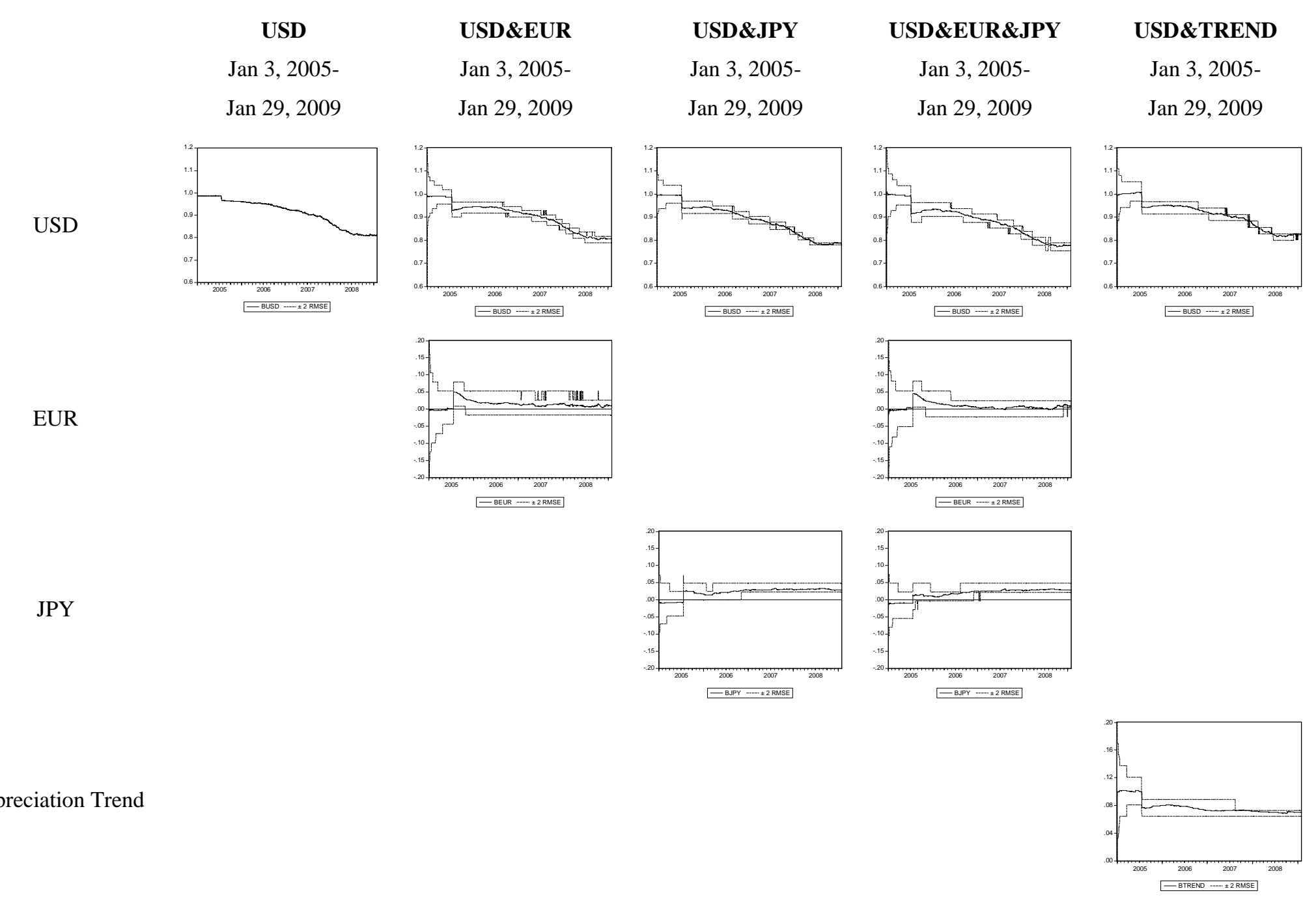


Then we include the US dollar and two selected currencies to the specification. The estimated weights for the Japanese yen remain positive also in this broader specification, while euro becomes insignificant.

While these results are largely similar to the previous findings using differenced data, it is important to note that time-varying coefficients show a stabilization of the US dollar already after July 2008. This result is more consistent with our expectations based on exchange rate developments in Figure 1. At the same time, the estimation still attributes some weight to the euro and the Japanese yen. ${ }^{5}$ Our approach based on the Kalman filter and the use of data in levels perform significantly better than the standard approach using regressions with differenced data.

Finally, we consider an appreciation trend in our estimations. It can be seen that the specification based on the US dollar and an appreciation trend is comparably robust. The results reveal that the appreciation trend received continuously lower weights during the analyzed period. This would imply that China's exchange rate policy can be described reasonably well as a fixed exchange rate policy with a predetermined appreciation trend. However, the information criteria reported in Table 3 favor the specification with the US dollar and the Japanese yen, but the statistics are only slightly better than the parsimonious specification including only the US dollar.

\section{Conclusions}

Economic policy announcements often differ from the perceived de facto policy. There are numerous examples among developed and developing countries or emerging economies. The Chinese exchange rate policy belongs to those cases which attracted significant attention in economic research and policy. The exchange rate of the renminbi is declared to be pegged to a basket of currencies, but several papers found evidence only for a peg to the US dollar. It was argued that other currencies are not actually used in the determination of the exchange rate in China.

We review these papers and argue that earlier studies had several drawbacks. First, they are based on differenced data and therefore cannot use information on any

\footnotetext{
${ }^{5}$ The coefficients for the euro and the Japanese yen become insignificant if the estimation period is extended to 2009 .
} 
movements behind instantaneous changes. Second, the results may be biased because of unexplained autocorrelation of the residuals. Indeed, we demonstrate that the standard approach fails to identify the policy change in the second half of 2008.

We propose an alternative estimation methodology with time-varying coefficients using the Kalman filter and data in levels. We show that this method yields excellent results. We confirm the previous findings on the continuing importance of the US dollar during the de jure floating period. We find only limited evidence that other currencies have played a role in the determination of the renminbi's exchange rate. In contrast, we can see an appreciation trend which continuously lost in importance during the period analyzed. These results indicate that the exchange rate of the renminbi was never freely floating. Finally, this approach reveals correctly the implicit change of the Chinese exchange rate policy in July 2008, which was implemented already before the outbreak of the financial crisis. While we analyzed only the period between July 2005 and the end of 2009, this approach can be used for the analysis of future changes of Chinese exchange rate policy, which were announced in June 2010.

\section{References}

Bussière, Matthieu, Fidrmuc, Jarko and Bernd Schnatz 2008: EU enlargement and trade integration: Lessons from a gravity model, Review of Development Economics 12, 501-515.

Calvo, Guillermo A. and Carmen M. Reinhart 2002: Fear of Floating. Quarterly Journal of Economics 117(2), 379-408.

Eichengreen, Barry and Hui Tong 2005: Is China's FDI coming at the expense of other countries, Working Paper No. 11335, NBER, Cambridge.

Frankel, Jeffrey A. 2006: On the Yuan: The Choice between Adjustment under a Fixed Exchange Rate and Adjustment under a Flexible Rate. CESifo Economic Studies 52(2), 246-275.

Frankel, Jeffrey A. 2009: New Estimation of China's Exchange Rate Regime. Pacific Economic Review 14 (3), 346-360.

Frankel, Jeffrey A., and Shang-Jin Wei 2007: Assessing China's Exchange Rate Regime. Working Papers 13100, National Bureau of Economic Research. 
Frankel, Jeffrey A., and Shang-Jin Wei 2008: Estimation of De Facto Exchange Rate Regimes: Synthesis of the Techniques for Inferring Flexibility and Basket Weights. IMF Staff Papers 55(3), 384-416.

Frankel, Jeffrey A., and Daniel Xie (2010): Estimation of De Facto Flexibility Parameter and Basket Weights in Evolving Exchange Rate Regimes, American Economic Review 100(2), 568-572.

Funke, Michael and Marc Gronwald 2008: The Undisclosed Renminbi Basket: Are the Markets Telling Us Something about Where the Renminbi-US Dollar Exchange Rate is Going? World Economy 31(12), 1581-1598.

Harvey, Andrew C. 1989: Forecasting, Structural Time Series Models and the Kalman Filter. Cambridge: Cambridge University Press.

Korhonen, Iikka, and Maria Ritola 2009: Renminbi Misaligned - Results from MetaRegressions. Discussion Papers No. 13/2009, Bank of Finland, Institute for Economies in Transition (BOFIT), Helsinki.

Meese, Richard. A. and Kenneth S. Rogoff 1983: Empirical Exchange Rate Models of the Seventies, Journal of International Economics, 14, pp. 3-24.

McKinnon, Ronald 2006: China's Exchange Rate Trap: Japan Redux? American Economic Review, 96(2), 427-431.

McKinnon, Ronald, Lee, Brian, and Wang, Yi David 2009: The Global Credit Crisis and China's Exchange Rate. Working Paper No. 391, SCID.

OECD 2010: OECD Economic Survey China, OECD, Paris.

Ogawa, Eiji, and Maichiru Sakane 2006: Chinese Yuan after Chinese Exchange Rate System Reform. China \& World Economy 14 (6), 39-57.

PBC 2010: Further Reform the RMB Exchange Rate Regime and Enhance the RMB Exchange Rate Flexibility. News of People's Bank of China, June 19, 2010, Beijing.

Reinhart, Carmen M., and Kenneth S. Rogoff 2002: The Modern History of Exchange Rate Arrangements: A Reinterpretation. Working Paper No. 8963, NBER, Cambridge

Reinhart, Carmen M., and Kenneth S. Rogoff 2004: The Modern History of Exchange Rate Arrangements: A Reinterpretation, Quarterly Journal of Economics 129, 1-48.

Reynard, Samuel 2008: What Drives the Swiss Franc? Working Paper No. 2008-14, Swiss National Bank. 


\section{CESifo Working Paper Series}

for full list see www.cesifo-group.org/wp

(address: Poschingerstr. 5, 81679 Munich, Germany, office@cesifo.de)

3085 Andrzej Baniak and Peter Grajzl, Interjurisdictional Linkages and the Scope for Interventionist Legal Harmonization, June 2010

3086 Oliver Falck and Ludger Woessmann, School Competition and Students' Entrepreneurial Intentions: International Evidence Using Historical Catholic Roots of Private Schooling, June 2010

3087 Bernd Hayo and Stefan Voigt, Determinants of Constitutional Change: Why do Countries Change their Form of Government?, June 2010

3088 Momi Dahan and Michel Strawczynski, Fiscal Rules and Composition Bias in OECD Countries, June 2010

3089 Marcel Fratzscher and Julien Reynaud, IMF Surveillance and Financial Markets - A Political Economy Analysis, June 2010

3090 Michel Beine, Elisabetta Lodigiani and Robert Vermeulen, Remittances and Financial Openness, June 2010

3091 Sebastian Kube and Christian Traxler, The Interaction of Legal and Social Norm Enforcement, June 2010

3092 Volker Grossmann, Thomas M. Steger and Timo Trimborn, Quantifying Optimal Growth Policy, June 2010

3093 Huw David Dixon, A Unified Framework for Using Micro-Data to Compare Dynamic Wage and Price Setting Models, June 2010

3094 Helmuth Cremer, Firouz Gahvari and Pierre Pestieau, Accidental Bequests: A Curse for the Rich and a Boon for the Poor, June 2010

3095 Frank Lichtenberg, The Contribution of Pharmaceutical Innovation to Longevity Growth in Germany and France, June 2010

3096 Simon P. Anderson, Øystein Foros and Hans Jarle Kind, Hotelling Competition with Multi-Purchasing: Time Magazine, Newsweek, or both?, June 2010

3097 Assar Lindbeck and Mats Persson, A Continuous Theory of Income Insurance, June 2010

3098 Thomas Moutos and Christos Tsitsikas, Whither Public Interest: The Case of Greece's Public Finance, June 2010

3099 Thomas Eichner and Thorsten Upmann, Labor Markets and Capital Tax Competition, June 2010 
3100 Massimo Bordignon and Santino Piazza, Who do you Blame in Local Finance? An Analysis of Municipal Financing in Italy, June 2010

3101 Kyriakos C. Neanidis, Financial Dollarization and European Union Membership, June 2010

3102 Maela Giofré, Investor Protection and Foreign Stakeholders, June 2010

3103 Andrea F. Presbitero and Alberto Zazzaro, Competition and Relationship Lending: Friends or Foes?, June 2010

3104 Dan Anderberg and Yu Zhu, The Effect of Education on Martial Status and Partner Characteristics: Evidence from the UK, June 2010

3105 Hendrik Jürges, Eberhard Kruk and Steffen Reinhold, The Effect of Compulsory Schooling on Health - Evidence from Biomarkers, June 2010

3106 Alessandro Gambini and Alberto Zazzaro, Long-Lasting Bank Relationships and Growth of Firms, June 2010

3107 Jenny E. Ligthart and Gerard C. van der Meijden, Coordinated Tax-Tariff Reforms, Informality, and Welfare Distribution, June 2010

3108 Vilen Lipatov and Alfons Weichenrieder, Optimal Income Taxation with Tax Competition, June 2010

3109 Malte Mosel, Competition, Imitation, and R\&D Productivity in a Growth Model with Sector-Specific Patent Protection, June 2010

3110 Balázs Égert, Catching-up and Inflation in Europe: Balassa-Samuelson, Engel's Law and other Culprits, June 2010

3111 Johannes Metzler and Ludger Woessmann, The Impact of Teacher Subject Knowledge on Student Achievement: Evidence from Within-Teacher Within-Student Variation, June 2010

3112 Leif Danziger, Uniform and Nonuniform Staggering of Wage Contracts, July 2010

3113 Wolfgang Buchholz and Wolfgang Peters, Equity as a Prerequisite for Stable Cooperation in a Public-Good Economy - The Core Revisited, July 2010

3114 Panu Poutvaara and Olli Ropponen, School Shootings and Student Performance, July 2010

3115 John Beirne, Guglielmo Maria Caporale and Nicola Spagnolo, Liquidity Risk, Credit Risk and the Overnight Interest Rate Spread: A Stochastic Volatility Modelling Approach, July 2010

3116 M. Hashem Pesaran, Predictability of Asset Returns and the Efficient Market Hypothesis, July 2010 
3117 Dorothee Crayen, Christa Hainz and Christiane Ströh de Martínez, Remittances, Banking Status and the Usage of Insurance Schemes, July 2010

3118 Eric O'N. Fisher, Heckscher-Ohlin Theory when Countries have Different Technologies, July 2010

3119 Huw Dixon and Hervé Le Bihan, Generalized Taylor and Generalized Calvo Price and Wage-Setting: Micro Evidence with Macro Implications, July 2010

3120 Laszlo Goerke and Markus Pannenberg, 'Take it or Go to Court' - The Impact of Sec. 1a of the German Protection against Dismissal Act on Severance Payments -, July 2010

3121 Robert S. Chirinko and Daniel J. Wilson, Can Lower Tax Rates be Bought? Business Rent-Seeking and Tax Competition among U.S. States, July 2010

3122 Douglas Gollin and Christian Zimmermann, Global Climate Change and the Resurgence of Tropical Disease: An Economic Approach, July 2010

3123 Francesco Daveri and Maria Laura Parisi, Experience, Innovation and Productivity Empirical Evidence from Italy's Slowdown, July 2010

3124 Carlo V. Fiorio and Massimo Florio, A Fair Price for Energy? Ownership versus Market Opening in the EU15, July 2010

3125 Frederick van der Ploeg, Natural Resources: Curse or Blessing?, July 2010

3126 Kaisa Kotakorpi and Panu Poutvaara, Pay for Politicians and Candidate Selection: An Empirical Analysis, July 2010

3127 Jun-ichi Itaya, Makoto Okamura and Chikara Yamaguchi, Partial Tax Coordination in a Repeated Game Setting, July 2010

3128 Volker Meier and Helmut Rainer, On the Optimality of Joint Taxation for NonCooperative Couples, July 2010

3129 Ryan Oprea, Keith Henwood and Daniel Friedman, Separating the Hawks from the Doves: Evidence from Continuous Time Laboratory Games, July 2010

3130 Mari Rege and Ingeborg F. Solli, The Impact of Paternity Leave on Long-term Father Involvement, July 2010

3131 Olaf Posch, Risk Premia in General Equilibrium, July 2010

3132 John Komlos and Marek Brabec, The Trend of BMI Values by Centiles of US Adults, Birth Cohorts 1882-1986, July 2010

3133 Emin Karagözoğlu and Arno Riedl, Information, Uncertainty, and Subjective Entitlements in Bargaining, July 2010 
3134 John Boyd, Gianni De Nicolò and Elena Loukoianova, Banking Crises and Crisis Dating: Theory and Evidence, July 2010

3135 Michael R. Baye, Dan Kovenock and Casper G. de Vries, The Herodotus Paradox, July 2010

3136 Martin Kolmar and Hendrik Rommeswinkel, Group Contests with Complementarities in Efforts, July 2010

3137 Carolina Manzano and Xavier Vives, Public and Private Learning from Prices, Strategic Substitutability and Complementarity, and Equilibrium Multiplicity, July 2010

3138 Axel Löffler, Gunther Schnabl and Franziska Schobert, Inflation Targeting by Debtor Central Banks in Emerging Market Economies, July 2010

3139 Yu-Fu Chen and Michael Funke, Global Warming and Extreme Events: Rethinking the Timing and Intensity of Environmental Policy, July 2010

3140 Lawrence M. Kahn, Labor Market Policy: A Comparative View on the Costs and Benefits of Labor Market Flexibility, July 2010

3141 Ben J. Heijdra, Jochen O. Mierau and Laurie S.M. Reijnders, The Tragedy of Annuitization, July 2010

3142 Erkki Koskela, Outsourcing Cost and Tax Progression under Nash Wage Bargaining with Flexible Outsourcing, July 2010

3143 Daniel Osberghaus and Christiane Reif, Total Costs and Budgetary Effects of Adaptation to Climate Change: An Assessment for the European Union, August 2010

3144 Philip E. Graves, Benefit-Cost Analysis of Environmental Projects: A Plethora of Systematic Biases, August 2010

3145 Sabrina Di Addario and Daniela Vuri, Entrepreneurship and Market Size. The Case of Young College Graduates in Italy, August 2010

3146 Shoshana Amyra Grossbard and Alfredo Marvăo Pereira, Will Women Save more than Men? A Theoretical Model of Savings and Marriage, August 2010

3147 Jarko Fidrmuc, Time-Varying Exchange Rate Basket in China from 2005 to 2009, August 2010 